\title{
TOLL-LIKE RECEPTORS (TLR) 2 AND 4 EXPRESSION OF KERATINOCYTES FROM PATIENTS WITH LOCALIZED AND DISSEMINATED DERMATOPHYTOSIS
}

Cristiane Beatriz de OLIVEIRA(1), Cídia VASCONCELLOS(1), Neusa Y. SAKAI-VALENTE(2), Mirian Nacagami SOTTO(1), Fernanda Guedes LUIZ(3), Walter BELDA JÚNIOR(1), Maria da Gloria Teixeira de SOUSA(2), Gil BENARD(2) \& Paulo Ricardo CRIADO(1)

\begin{abstract}
SUMMARY
There are few studies on the role of innate immune response in dermatophytosis. An investigation was conducted to define the involvement of Toll-Like Receptors (TLRs) 2 and 4 in localized (LD) and disseminated (DD) dermatophytosis due to T. rubrum. Fifteen newly diagnosed patients, eight patients with LD and seven with DD, defined by involvement of at least three body segments were used in this study. Controls comprised twenty skin samples from healthy individuals undergoing plastic surgery. TLR2 and TLR4 were quantified in skin lesions by immunohistochemistry. A reduced expression of TLR4 in the lower and upper epidermis of both LD and DD patients was found compared to controls; TLR2 expression was preserved in the upper and lower epidermis of all three groups. As TLR4 signaling induces the production of inflammatory cytokines and neutrophils recruitment, its reduced expression likely contributed to the lack of resolution of the infection and the consequent chronic nature of the dermatophytosis. As TLR2 expression acts to limit the inflammatory process and preserves the epidermal structure, its preserved expression may also contribute to the persistent infection and limited inflammation that are characteristic of dermatophytic infections.
\end{abstract}

KEYWORDS: Toll like receptor 2; Toll like receptor 4; Dermatophytosis; Trichophyton rubrum.

\section{INTRODUCTION}

Dermatophytosis is the infection of keratinized structures caused by members of the fungi of the genera Trichophyton, Epidermophyton and Microsporum. These fungi are adapted to infect keratinized tissues by virtue of their ability to utilize keratin as a nutrient source. Sites of infection include hair, nails, and the stratum corneum of the skin ${ }^{24,26}$. The clinical presentation of dermatophytosis depends on several factors: (i) the site of infection, (ii) the immunological response of the host, and (iii) the species of infecting fungus ${ }^{20}$. More than 40 dermatophyte species that infect humans (anthropophilic), animals (zoophilic) or are present in soil (geophilic) have been identified ${ }^{20}$. The infections caused by the anthropophilic species tend to be chronic but the resultant inflammation is $\operatorname{minimal}^{20,21}$

About $90 \%$ of chronic dermatophyte infections are caused by $T$. rubrum and T. mentagrophytes ${ }^{8,9}$, possibly because these organisms may suppress inflammation and cell-mediated immunity ${ }^{7}$.

Keratinocyte is the predominant cell type in the epidermis, comprising over $90 \%$ of the cells ${ }^{5}$. However, during an inflammatory process the innate immune network of the epidermis consists of not only the pre-existing keratinocytes, but also of rapidly mobilized host defense cellular components such as neutrophils, mast cells, eosinophils, and macrophages ${ }^{25}$. Recognition of pathogens by innate immune cells is mediated by pattern recognition receptors (PRRs) that recognize conserved pathogen-associated molecular patterns (PAMPs). Toll-like receptors (TLRs) are a family of PRRs that have recently been identified as crucial signaling receptors mediating the innate immune recognition, and comprise a family of 10 receptors with distinct recognition profiles in humans ${ }^{17}$. Human keratinocytes are known to express TLRs 1 to 6 and TLR9 $9^{3,10,11,14,15,19,22}$.

Although it is known if certain elements of the fungal wall increase TLR expression upon recognition by these receptors, a previous in vitro study demonstrated that whole Trichophyton rubrum conidia could diminish TLR expression on a keratinocyte cell line ${ }^{7}$. However, there are few studies on human immune response to dermatophytes. In this study it is demonstrated that TLR4 expression is lower on keratinocytes of patients with either localized or disseminated dermatophytosis compared with normal skin.

\section{PATIENTS AND METHODS}

Two groups of patients with dermatophytosis were evaluated: seven patients with disseminated dermatophytosis (involving at least

(1) Department of Dermatology, Medical School, University of Sao Paulo, São Paulo, SP, Brazil.

(2) Laboratory of Medical Investigation Unit 53, Division of Clinical Dermatology, Medical School, University of Sao Paulo, São Paulo, SP, Brazil.

(3) Instituto Pasteur de São Paulo, Laboratório de Diagnóstico da Raiva, São Paulo, SP, Brazil.

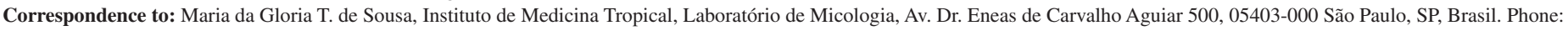
+551130617499, Fax: +55 11 30817190. E-mail: sousa.gloria@gmail.com 


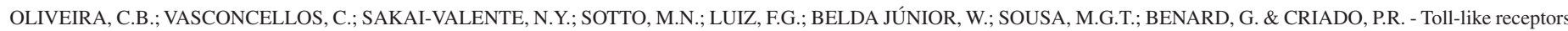
(TLR) 2 and 4 expression of keratinocytes from patients with localized and disseminated dermatophytosis. Rev. Inst. Med. Trop. Sao Paulo, 57(1): 57-61, 2015.

three distinct body parts), and eight with localized dermatophytosis (involvement of only one body part). All of the patients were recruited from the Mycology Outpatient Clinic of the Division of Clinical Dermatology, Clinics Hospital, University of São Paulo. Twenty skin samples from healthy individuals undergoing plastic surgery were included as controls. The following inclusion criteria were used: (i) the subjects had dermatophytosis but did not present any comorbidity affecting the immune response or predisposing them to dermatophytosis (e.g., primary or secondary immunosuppression, diabetes mellitus, Cushing's disease, transplant recipients); (ii) T. rubrum was the fungal agent; and (iii) the subjects had not used topical or systemic treatments in the last month. Patients who were under 18 years of age or pregnant were excluded. All patients signed an informed consent form previous to inclusion in the study. The study was approved by the Ethics Committee of the Clinics Hospital, University of São Paulo Medical School (\#673/06). Identification of T. rubrum was done by microscopic examination of samples obtained from lesions that had been cultured in Agar Sabouraud ${ }^{13}$ (Becton, Dickinson and Company, Heidelberg/Germany).

Immunohistochemistry of the biopsies of the lesions: Biopsies were taken with a standard dermatological biopsy punch. For the patients with dermatophytosis, two biopsies were taken: one on the border of the active lesion and another from unaffected skin on the same body part at least $4 \mathrm{~cm}$ away from the affected area. Twenty controls were obtained from cosmetic surgery.

Slides were dewaxed in xylene and hydrated through a graded series of ethanol. Endogenous peroxidase was blocked with $3 \%$ hydrogen peroxide. Antigen retrieval for TLR2 and TLR4 analysis was performed by incubation of slides in retrieval solution $\mathrm{pH} 9.0$ (S2368, DakoCytomation, Carpinteria, CA, E.U.A) in a water bath for $25 \mathrm{~min}$ at $95{ }^{\circ} \mathrm{C}$. They were then incubated overnight at $4{ }^{\circ} \mathrm{C}$ in the presence of a 1:50 dilution of anti-TLR2 primary antibody (sc-10739, Santa Cruz Biotechnology, Santa Cruz, CA, U.S.A) and a 1:400 dilution of anti-TLR4 primary antibody (ab47093, Abcam, Cambridge, MA, U.S.A). The specific antigen-antibody reactions were detected with an alkaline-phosphatase-based system (EnVision ${ }^{\mathrm{TM}} \mathrm{G} 2$ system/AP; DakoCytomation, Carpinteria, CA, U.S.A.) for TLR2 and a streptavidin-biotin-peroxidase-based system for TLR4, according to the manufacturer's instructions ( $\mathrm{LSAB}^{\mathrm{TM}}+$ system-HRP; DakoCytomation, Carpinteria, CA, U.S.A.). The reactions for TLR2 were visualized using Liquid Permanent Red chromogen (DakoCytomation) and the reactions for TLR4 were visualized using the 3,3'-diaminobenzidinetetrahydrochloride (DAB) chromogen (Sigma) and counterstained with Carazzi haematoxylin.

All reactions were performed with positive and negative controls. The latter comprised omission of the primary antibody.

Quantification of immunostained cells was performed using AxioVision 4.8.2 software (Zeiss).

Image analysis: The epidermis was photographed along its entire length under a 10X eyepiece and a 20X objective coupled to a Carl Zeiss AxioCam MR3 camera mounted on a Zeiss Axiophot optical microscope. The images were analyzed using the Image Pro Plus program. Prior to quantification, the epidermis was divided into upper epidermis (surface) and lower epidermis (deep tissue) at $50 \%$ of its thickness.
Each measurement unit contained 3.11 pixels. The image analysis system measured the mean color density of the immunohistochemical staining in the epidermis, which represents the mean intensity of the staining within the positive area (range, 0-255) ${ }^{18}$. The expression of TLRs 2 and 4 in the epithelium was calculated as the product of the area of positive staining and mean density, normalized by the corresponding epithelial basement membrane length ${ }^{18}$. This index of protein expression takes into account both the intensity and the area of staining. A simple average of the values for each photographic field on the same slide was used.

Statistical analysis: The number of positive cells of the three groups of tissue reaction was compared using Graph Pad Prism version 5.00 for Windows (Graph Pad software, San Diego, CA, USA) to perform a Kruskal Wallis and Dunn's post test with the level for significance set at $95 \%$.

\section{RESULTS}

The average age for the groups were as follows: 35 (range: 19-51) years for the patients with DD, 39 (range: 18-62) years for those with LD, and 57 (range: 46-72) for the controls. The average disease progression time was 16 (range: $2-60$ ) months in the patients with DD and 19 (range: 1-60) months in the patients with LD.

Hematoxilin staining did not reveal any inflammatory infiltrate in the epidermis of the patients (data not shown), which was unremarkable when compared with that of the healthy skin biopsies.

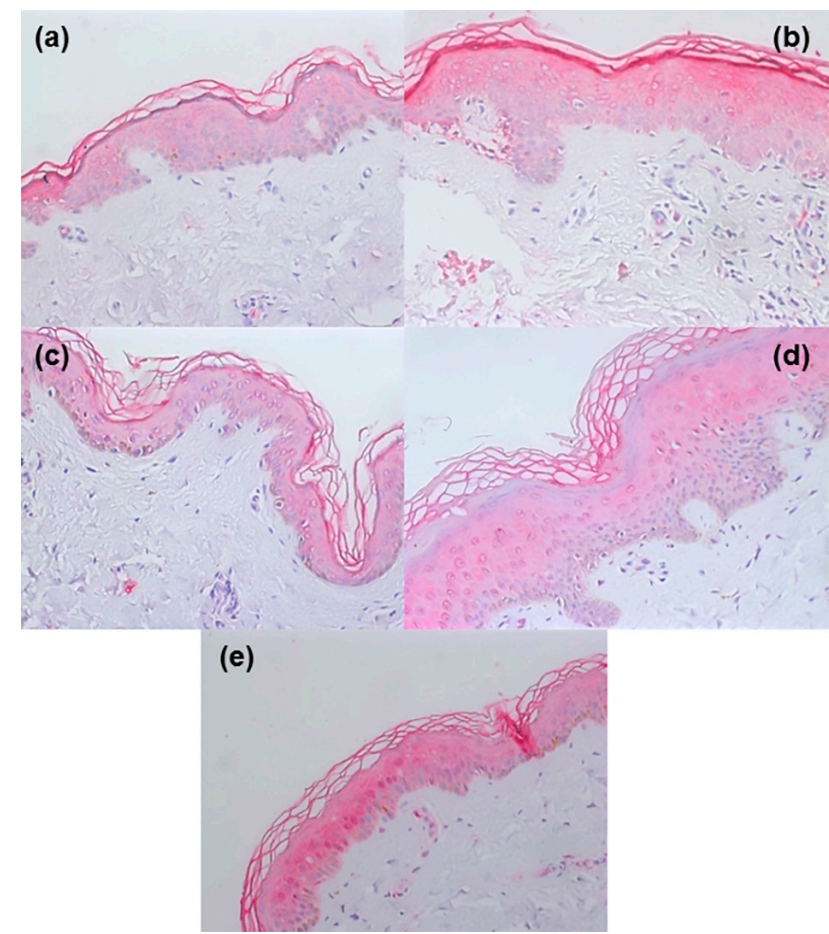

Fig. 1 - TLR2 expression in unaffected (a) and affected (b) epidermis from an individual with localized dermatophytosis and in unaffected (c) and affected (d) epidermis from an individual with disseminated dermatophytosis. (e) shows TLR2 expression in the epidermis of a healthy individual. Magnification: x200 

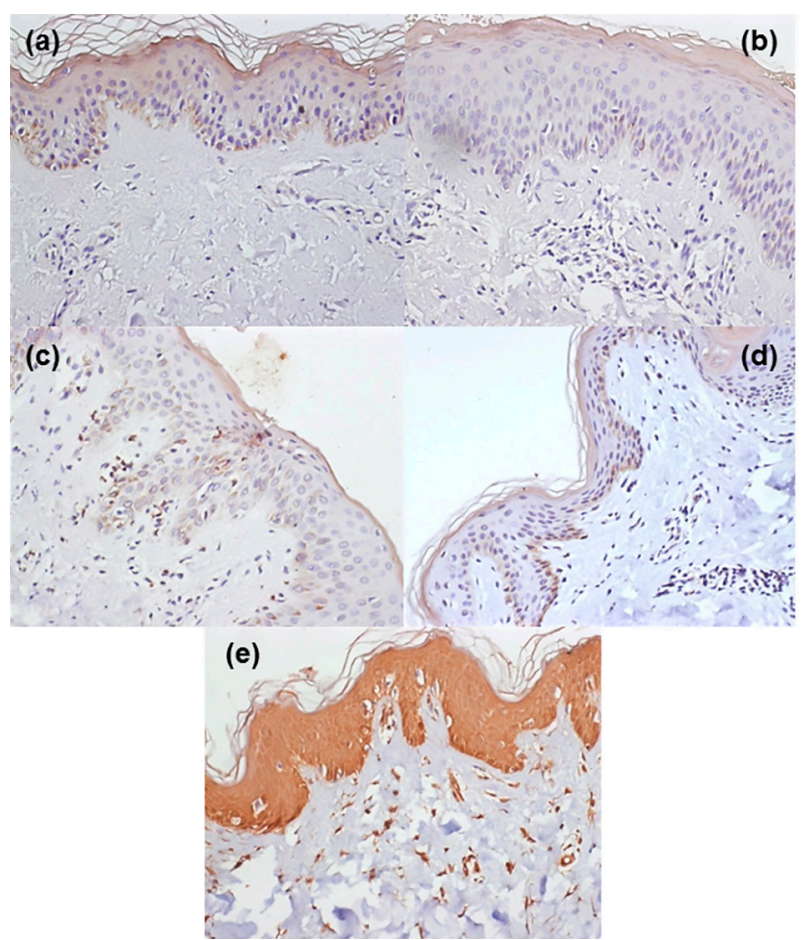

Fig. 2 - TLR4 expression in unaffected (a) and affected (b) epidermis from an individual with localized dermatophytosis and in unaffected (c) and affected (d) epidermis from an individual with disseminated dermatophytosis. (e) shows TLR4 expression in the epidermis of a healthy individual. Magnification: x200

TLR4 expression was reduced in the upper epidermis of either LD or DD dermatophytosis patients, as compared with the control group (Fig. 3A). The TLR4 staining optical density index was $145 \pm 22$ in the controls, compared with $109 \pm 9$ in biopsies of LD patients and $110 \pm$ 15 of the DD patients $(p<0.001)$. Interestingly, TLR4 expression in unaffected skin in both dermatophytosis groups was similar to that in the respective affected areas (LD: $109 \pm 9$; DD: $110 \pm 7$ ), and significantly reduced compared with the control group ( $p<0.001)$ (Fig. 3A). There were no differences between individuals with LD and DD (Fig. 2a, 2b, 2c, $2 \mathrm{~d}$ and $2 \mathrm{e})$.

No differences were observed in TLR4 expression between unaffected and affected skin samples in the two patient groups. In addition, there were no differences between individuals with LD and DD (Fig. 2a, 2b, 2c and 2d).

In the lower epidermis, TLR4 expression was also lower in patients with dermatophytosis than in controls (Fig. 3A). The optical density index was $145 \pm 17$ in controls and $111 \pm 7$ and $111 \pm 13$ respectively in the unaffected and affected areas of DD patients (Fig. 3A). In patients with $\mathrm{LD}$, the optical density indices were respectively $111 \pm 8$ and $110 \pm 5$. As in the upper epidermis, there were no differences between unaffected and affected skin areas (Fig. 2a, 2b, 2c and 2d).

TLR2 expression was diffusely detected in the upper and lower epidermis of both patients and controls (Fig. 1 and 3B). In contrast to the TLR4 findings, no differences were detected in TLR2 expression in the upper and lower epidermis in the LD and DD when compared with

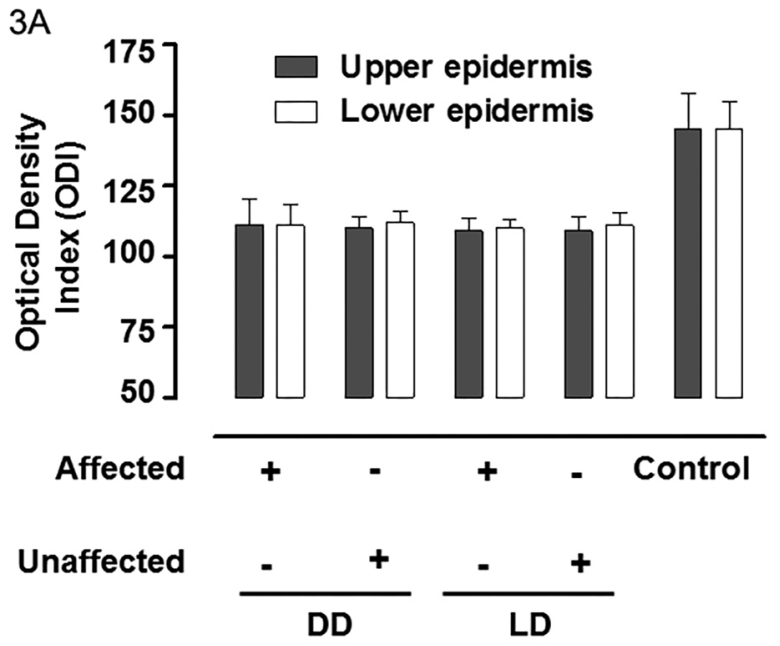

3B

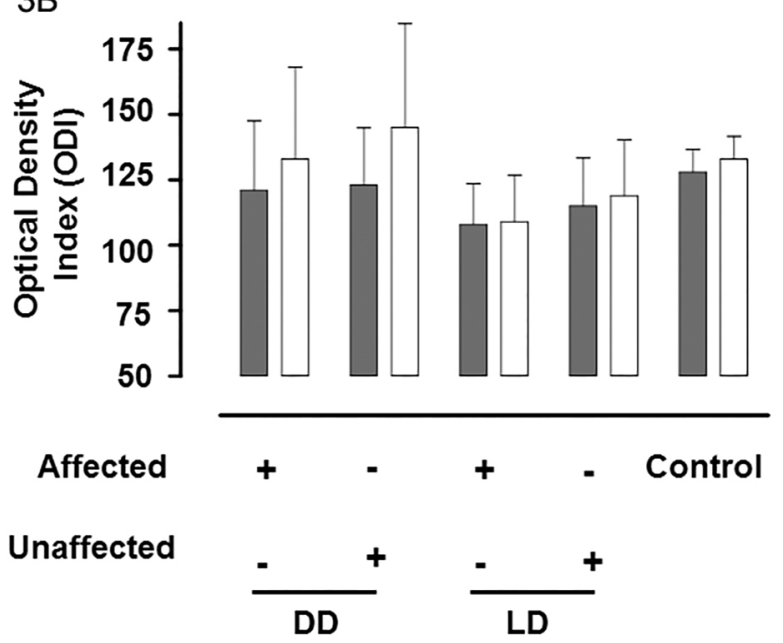

Fig. 3 - (A) Comparison of TLR4 expression in unaffected and affected skin of patients with disseminated (DD) and localized dermatophytosis (LD), and in skin of healthy controls. (B) A comparison of TLR2 expression in unaffected and affected skin of patients with DD or LD and in skin of healthy controls. TLR4 and TLR2 expression were quantified based on the optical density index (ODI) of the lower and upper epidermis layers. Results are presented as mean \pm SEM. $* p=0.01$.

the control group. The intensity of expression of TLRs 2 and 4 in the epidermis was apparently comparable, although this comparison should be regarded with caution since the chromogens used for each staining differed.

\section{DISCUSSION}

T. rubrum infections are often chronic and result in minor inflammation. Additionally, these infections are marked by polarization during the immediate immune response and the later inadequate cellular response ${ }^{26}$. The patients in this study had chronic disease; patients with both the disseminated and localized forms had an average duration of more than one year. Accordingly, no inflammatory infiltrate in the epidermis of the infected skin areas was observed. The reasons for such lack of inflammatory response are not yet known. 


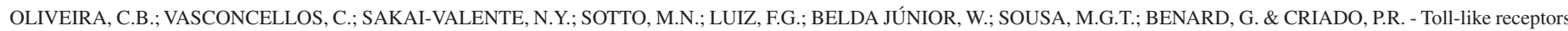
(TLR) 2 and 4 expression of keratinocytes from patients with localized and disseminated dermatophytosis. Rev. Inst. Med. Trop. Sao Paulo, 57(1): 57-61, 2015.

Recognition of pathogens by innate immune cells is mediated by PRRs that recognize PAMPs. TLRs (comprising a family of 10 receptors with distinct recognition profiles in humans) act as pattern recognition receptors and these receptors are able to recognize fungi and polarize the immune response ${ }^{1,2}$. Various cell subtypes express these receptors, including human keratinocytes, which express TLRs 1 to 6 , and TLR9 ${ }^{6,23}$. Moreover, TLR2 is highly expressed in normal skin, particularly in proliferating basal keratinocytes, but TLR4 is less detectable by immunostaining ${ }^{3,19}$. Constitutive expression of mRNA specific for both TLR2 and TLR4 has recently been demonstrated in cultured human keratinocytes and gingival epithelial cells ${ }^{19}$. A report showed that TLR2 mRNA was more prominently upregulated in normal human keratinocytes than TLR4 mRNA $^{19}$. Thus keratinocytes may act both as a mechanical and an immunological barrier to pathogens, the latter by triggering an innate immune response to control the infectious process $^{3,5}$.

Among TLR family members, both TLR2 and TLR4 have been shown to recognize bacterial and fungal components and mediate the production of the cytokines required for the development of an effective immunity. TLR2 has been implicated in the recognition of Gram-positive bacteria components, bacterial lipoproteins, and zymosan while TLR4 recognizes lipopolysaccharide (LPS) and O-linked mannans ${ }^{1}$.

Here, marked TLR2 and TLR4 expression was observed across the entire thickness of the epidermis of patients with LD and DD, confirming previously published studies on the expression of TLR2 and TLR4 on keratinocytes $^{3,10,11}$

No significant differences were observed between TLR2 and TLR4 expression levels in both the upper epidermis and lower epidermis when dermatophytosis patients and controls were compared, as has been described in normal epidermis s $^{3,11,15,19,22}$. However, reduced TLR4 was detected, but not TLR2 expression, in the upper and lower epidermis layer in both DD and LD patients when compared with the control group. This reduced expression was equally observed in patients with LD and DD in the sample group of this study.

The expression of TLRs 2 and 4 in the biopsies of affected (dermatophytosis) and adjacent unaffected (healthy skin) areas of the patients were also compared. There were no differences in the expression between unaffected and affected areas. As a constitutive defect in TLR4 seems unlikely, it is conceivable that the down modulation present in the affected skin spreads to adjacent, seemingly clinically healthy areas.

Another important observation is that there was no difference in the expression of the TLR between individuals with LD or DD. Therefore, this suggests that TLR2 and TLR4 expression levels do not explain the more extensive lesions. GARCÍA-MADRID et al. (2011) showed that keratinocytes can recognize and respond to cell wall components of T. rubrum. Viable intact conidia inhibited TLR2 and TLR6 expression by cultured human keratinocytes while conidial homogenate from T. rubrum increased the expression of TLR2, TLR4 and TLR6 ${ }^{7}$. Recently, YUKI et al. ${ }^{27}$ demonstrated that TLR2 activation enhances tight junctions among keratinocytes, a crucial step in maintaining the functional activity of epidermal barriers against infective agents, such as bacteria or fungi. TLR2 inhibition increased the permeability of the cutaneous barrier, thereby decreasing the cohesion between keratinocytes and facilitating fungal invasion ${ }^{27}$. Thus, the appropriate TLR2 expression in the upper epidermis layer would represent a protective mechanism inhibiting the fungal invasion and dissemination into the epidermis while limiting the inflammatory process and reducing tissue damage.

Contrary to this protective effect of TLR2 on keratinocytes tight junctions, there is evidence that TLR4 induces the production of inflammatory cytokines and neutrophils recruitment. Furthermore, TLR2 has been shown to induce a Th- 2 response ${ }^{10,11}$. Thus, predominance of TLR2-induced Th-2 response would not be appropriate for the elimination of the invading dermatophytes, explaining at least in part the chronic nature and extension of the lesions. The association with the decreased expression in superficial epidermis of TLR4, and the consequent decrease in pro-inflammatory cytokines production and neutrophil recruitment would, in turn, explain the limited inflammatory response in the lesions caused by $T$. rubrum. In addition, Th 2 responses can also inhibit Th17 responses, which are potent inducers of neutrophil infiltration and production of pro-inflammatory cytokines ${ }^{4,12,14,16}$.

In conclusion, these results demonstrate reduced expression of TLR4, a signaling receptor that recognizes important bacterial (lipopolysaccharide) and fungal (O-linked mannans) components, in the epidermis of dermatophotysis lesions. This down modulation may represent a mechanism underlying the reduced inflammatory response observed in this cutaneous fungal infection. Elucidation of the mechanisms by which T. rubrum interferes with the role of keratinocytes in the initial stage of the innate immune response is essential to the development of better therapeutic strategies.

\section{RESUMO}

\section{Expressão de receptores do tipo Toll 2 e 4 nos queratinócitos de pacientes com dermatofitose localizada e disseminada}

A literatura sobre o papel da resposta imune inata em dermatofitose é escassa. Este estudo se propôs a investigar a participação dos receptores do tipo Toll 2 e 4 (TLRs) 2 e 4 em pacientes com dermatofitose localizada (LD) e disseminada (DD, definida como lesões em pelo menos três segmentos corpóreos distintos), causadas por Trichophyton rubrum. Foram analisados cortes histológicos de 15 pacientes recémdiagnosticados, oito com LD e sete com DD. O grupo controle foi composto por 20 amostras de pele de indivíduos saudáveis submetidos a cirurgia plástica. TLR-2 e TLR-4 foram quantificados em lesões cutâneas por imunohistoquímica. Encontramos uma expressão reduzida de TLR-4 na epiderme superior e inferior nos dois grupos, LD e DD, quando comparados com o grupo controle; a expressão de TLR-2 foi preservada na epiderme superior e inferior de todos os três grupos. Como a sinalização por TLR-4 induz produção de citocinas inflamatórias e recrutamento de neutrófilos, a menor expressão desta molécula provavelmente contribui para a não resolução da infecção e conseqüente natureza persistente da dermatofitose. Como a sinalização via TLR-2 tem sido descrita como fator de regulação do processo inflamatório e de preservação da estrutura epidérmica, a sua expressão inalterada nas lesões dos pacientes com DD e DL pode contribuir também para a persistência da infecção e do reduzido processo inflamatório que são característicos das infecções por dermatófitos. 


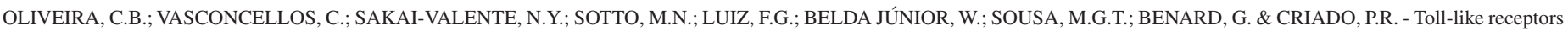
(TLR) 2 and 4 expression of keratinocytes from patients with localized and disseminated dermatophytosis. Rev. Inst. Med. Trop. Sao Paulo, 57(1): 57-61, 2015.

\section{ACKNOWLEDGMENTS}

Financial support: This work was supported by Fundação de Amparo à Pesquisa do Estado de São Paulo (contracts \#11/51001-1 and \#2010/19369-6). GB is a senior researcher of the Conselho Nacional para o Desenvolvimento Científico e Tecnológico.

\section{CONFLICTS OF INTEREST}

The authors declare no conflicts of interest.

\section{REFERENCES}

1. Akira S, Taheda K. Toll like receptor signaling. Nat Rev Immunol. 2004;4:499-511.

2. Arancibia SA, Beltrán CJ, Aguirre IM, Silva P, Peralta AL, Malinarich F, et al. Toll-like receptors are key participants in innate immune responses. Biol Res. 2007;40:97-112.

3. Baker BS, Ovigne JM, Powles AV, Corcoran S, Fry L. Normal keratinocytes express Toll-like receptors (TLRs) 1,2 and 5: modulation of TLR expression in chronic plaque psoriasis. Br J Dermatol. 2003;148:670-9.

4. Crome SQ, Wang AY, levings MK. Translational mini-review series on Th17 cells: function and regulation of human T helper 17 cells in health and disease. Clin Exp Immunol. 2010;159:109-19.

5. Eckert, RL. Structure, function, and differentiation of the keratinocytes. Physiol Rev. 1989;69:1316-46.

6. Ermertcan AT, Öztürk F, Gündüz K. Toll-like receptors and skin. J Eur Acad Dermatol Venerol. 2011;25:997-1006.

7. García-Madrid LA, Huizar-López M del R, Flores-Romo L, Islas-Rodríguez AE. Trichophyton rubrum manipulates the innate immune functions of human keratinocytes. Cent Eur J Biol. 2011;6:902-10.

8. Hay RJ. Chronic dermatophyte infections. I. Clinical and mycological features. $\mathrm{Br}$ J Dermatol. 1982;106:1-7.

9. Ikuta K, Shibata N, Blake JS, Dahl M, Nelson RD, Hisamich K, et al. NMR study of the galactomannans of Trichophyton mentagrophytes and Trichophyton rubrum. Biochem J. 1997;323(Pt 1):297-305

10. Kawai K, Shimura H, Minagawa M, Ito A, Tomiyama K, Ito M. Expression of functional Toll-like receptor 2 on human epidermal keratinocytes. J. Dermatol Sci. 2002;30:185-94

11. Kollisch G, Kalali BN, Voelcker V, Wallich R, Behrendt H, Ring J, et al. Various members of the Toll-like receptor family contribute to the innate immune response of human epidermal keratinocytes. Immunology. 2004;114:531-41.

12. Kurebayashi Y, Nagai S, Ikejiri A, Koyasu S. Recent advances in understanding the molecular mechanisms of the development and function of Th17 cells. Genes Cells. 2013;18:247-65
13. Lacaz CS, Porto E, Martins JEC, Heins-Vaccari EM, Takahashi de Melo N. Tratado de micologia médica. 9 ed. São Paulo: Sarvier; 2002.

14. Mempel M, Voelcker V, Kollisch G, Plank C, Rad R, Gerhard M, et al. Toll-like receptor expression in human keratinocytes: nuclear factor kappaB controlled gene activation by Staphylococcus aureus is Toll-like receptor 2 but not Toll-like receptor 4 or platelet activating factor receptor dependent. J Invest Dermatol. 2003;121:1389-96.

15. Miller LS, Modlin RL. Toll-like receptors in the skin. Semin Immunopathol. 2007;29:15-26.

16. Miossec P, Kolls JK. Targeting IL-17 and Th17 cells in chronic inflammation. Nat Rev Drug Discov. 2012;11:763-76.

17. O'Neill LAJ, Golenbock D, Bowie AG. The history of Toll-like receptors -redefining innate immunity. Nat Rev Immunol. 2013;13:453-60.

18. Pires-Neto RC, Morales MMB, Lancas T, Inforsato N, Duarte MIS, Amato MBP, et al Expression of acute-phase cytokines, surfactant proteins, and epithelial apoptosis in small airways of human acute respiratory distress syndrome. J Crit Care. 2008;28:111 e9-e15.

19. Pivarcsi A, Bodai L, Réthi B, Kenderessy-Szabó A, Koreck A, Széli M, et al. Expression and function of Toll-like receptors 2 and 4 in human keratinocytes. Int Immunol. 2003;15:721-30

20. Richardson MD. Dermatophytosis. In: Richardson MD, Warnock DW. Fungal infection: diagnosis and management. Oxford: Blackwell; 1997. p. 59-60.

21. Rippon JW. The changing epidemiology and emerging patterns of dermatophyte species. In: McGinnis MR, editor. Current topics in medical mycology. New York: Springer-Verlag; 1985. p. 208-34

22. Song PI, Park YM, Abraham T, Harten B, Zivony A, Neparidze N, et al. Human keratinocytes express functional CD14 and toll-like receptor 4. J Invest Dermatol. 2002;119:424-32

23. Terhorst D, Kalali BN, Ollert M, Ring J, Mempel M. The role of toll-like receptors in host defenses and their relevance to dermatologic diseases. Am J Clin Dermatol 2010;11:1-10

24. Weitzman I, Summerbell RC. The dermatophytosis. Clin Microbiol Rev.1995;8:24059

25. Wollenberg A, Klein E. Current aspects of innate and adaptive immunity in atopic dermatitis. Clin Rev Allerg Immunol. 2007;33:35-44.

26. Woodfolk JA, Platts-Mills TA. The immune response to dermatophytes. Res Immunol. 1998;149:436-45.

27. Yuki T, Yoshida H, Akazawa Y, Komiya A, Sugiyama Y, Inoue S. Activation of TLR2 enhances tight junction barrier in epidermal keratinocytes. J Immunol. 2011;187:3230-

Received: 18 March 2014

Accepted: 6 August 2014 